\title{
Summary of Operations and Performance of the Utica Aquifer and North Lake Basin Wetlands Restoration Project in December 2010-November 2011
}

Environmental Science Division 
About Argonne National Laboratory

Argonne is a U.S. Department of Energy laboratory managed by UChicago Argonne, LLC under contract DE-AC02-06CH11357. The Laboratory's main facility is outside Chicago, at 9700 South Cass Avenue, Argonne, Illinois 60439. For information about Argonne and its pioneering science and technology programs, see www.anl.gov.

\section{Availability of This Report}

This report is available, at no cost, at http://www.osti.gov/bridge. It is also available on paper to the U.S. Department of Energy and its contractors, for a processing fee, from:

U.S. Department of Energy

Office of Scientific and Technical Information

P.O. Box 62

Oak Ridge, TN 37831-0062

phone (865) 576-8401

fax (865) 576-5728

reports@adonis.osti.gov

\section{Disclaimer}

This report was prepared as an account of work sponsored by an agency of the United States Government. Reference herein to any specific commercial product, process, or service by trade name, trademark, manufacturer, or otherwise, does not necessarily constitute or imply its endorsement, recommendation, or favoring by the United States Government or any agency thereof. The views and opinions of document authors expressed herein do not necessarily state or reflect those of the United States Government or any agency thereof, Argonne National Laboratory, or UChicago Argonne, LLC. 


\section{Summary of Operations and Performance of the Utica Aquifer and North Lake Basin Wetlands Restoration Project in December 2010-November 2011}

by

Applied Geosciences and Environmental Management Section Environmental Science Division, Argonne National Laboratory

January 2012 


\section{Contents}

Notation.

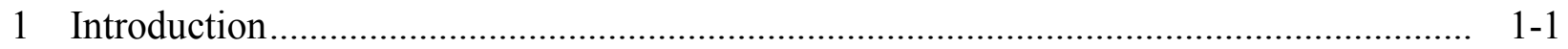

2 Overview of the Aquifer Restoration Facilities at Utica ............................................... 2-1

2.1 Wells GWEX1-GWEX3 and the Spray Irrigation Treatment Units....................... 2-1

2.2 Well GWEX4 and the Conventional Air Stripper ............................................ 2-1

2.3 Monitoring Well Network ........................................................................... 2-2

3 Overview of System Operations .................................................................................. $3-1$

3.1 Operation of Wells GWEX1-GWEX3 and the Spray Irrigation Treatment Units ...... 3-1

3.2 Operation of Well GWEX4 and the Conventional Air Stripper .............................. 3-1

4 Groundwater Production Results ............................................................................... 4- 4-1

4.1 Production by Wells GWEX1-GWEX3 …....................................................... 4-1

4.2 Production by Well GWEX4 …...................................................................... $4-2$

5 Groundwater Treatment Results ............................................................................ 5-1

5.1 Results for Wells GWEX1-GWEX3, with Treatment by Spray Irrigation ............. 5-2

5.2 Results for Well GWEX4, with Treatment by Air Stripping................................. 5-3

5.3 Estimated Removal of Carbon Tetrachloride from the Utica Aquifer...................... 5-4

5.4 Sampling of Monitoring Wells and Apparent Carbon Tetrachloride

Concentration Trends in the Utica Groundwater ............................................... $5-4$

5.5 Groundwater Inorganic Geochemistry......................................................... $5-6$

6 Operation, Maintenance, and System Modifications ...................................................... 6-1

6.1 Wells GWEX1-GWEX3 and the Spray Irrigation Treatment Units...................... 6-1

6.2 Well GWEX4 and the Air Stripping Unit................................................... $6-2$

6.3 Operating and Maintenance Costs ............................................................... $6-3$

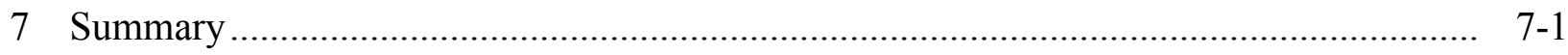

8 References ............................................................................................ 8 - 


\section{Figures}

2.1 Locations of the restoration facilities, contaminant plume, and permanent monitoring wells at Utica

2.2 Spray irrigation unit in operation at Utica

5.1 Carbon tetrachloride concentrations at monitoring wells MW1-MW4, September 2005 to November 2011

5.2 Carbon tetrachloride concentrations at extraction well GWEX1, November 2004 to November 2011.

5.3 Carbon tetrachloride concentrations at extraction well GWEX2, November 2004 to November 2011.

5.4 Carbon tetrachloride concentrations at extraction well GWEX3, November 2004 to November 2011.

5.5 Carbon tetrachloride concentrations at extraction well GWEX4, November 2004 to November 2011.

\section{Tables}

2.1 Summary of Construction Details for GWEX Wells at Utica

4.1 GWEX operation and groundwater production data in December 2010November 2011

4.2 Comparison of actual well production rates and target rates.

5.1 Analytical results for carbon tetrachloride in untreated groundwater samples and treated effluent samples in December 2010-November 2011

5.2 Values for $\mathrm{pH}$ in untreated groundwater samples and treated effluent samples in December 2010-November 2011

5.3 Estimation of carbon tetrachloride removed from the Utica aquifer in December 2010-November 2011

5.4 Results of the carbon tetrachloride removal efforts in October 2004-November 2011. 
Utica Annual Review, December 2010-November 2011

Version 00, 01/05/12

5.5 Well construction data and analytical results for carbon tetrachloride in groundwater samples from the permanent monitoring wells

6.1 Summary of operating and maintenance costs for the Utica restoration project .......... 6-4

7.1 Summary of performance of the groundwater restoration systems at Utica................. 7-3

7.2 Results of the groundwater extraction efforts, October 2004-November 2011 ............ 7-4 


\section{Notation}

$\begin{array}{ll}\text { BGL } & \text { below ground level } \\ \text { CCC } & \text { Commodity Credit Corporation } \\ \text { EPA } & \text { U.S. Environmental Protection Agency } \\ \mathrm{ft} & \text { foot (feet) } \\ \text { gal } & \text { gallon(s) } \\ \text { gpm } & \text { gallon(s) per minute } \\ \text { GWEX } & \text { groundwater extraction } \\ \text { hr } & \text { hour(s) } \\ \text { in. } & \text { inch(es) } \\ \text { kg } & \text { kilogram(s) } \\ \text { L } & \text { liter(s) } \\ \mu \mathrm{g} / \mathrm{L} & \text { microgram(s) per liter } \\ \text { MCL } & \text { maximum contaminant level } \\ \text { MW } & \text { monitoring well } \\ \text { NDEQ } & \text { Nebraska Department of Environmental Quality } \\ \text { NGPC } & \text { Nebraska Game and Parks Commission } \\ \text { NPDES } & \text { National Pollutant Discharge Elimination System } \\ \text { USDA } & \text { U.S. Department of Agriculture } \\ \text { VOC } & \text { volatile organic compound } \\ \text { yr } & \text { year(s) }\end{array}$




\section{Summary of Operations and Performance of the Utica Aquifer and North Lake Basin Wetlands Restoration Project in December 2010-November 2011}

\section{Introduction}

This document summarizes the performance of the groundwater restoration systems installed by the Commodity Credit Corporation of the U.S. Department of Agriculture (CCC/USDA) at the former CCC/USDA grain storage facility in Utica, Nebraska, during the seventh year of system operation, from December 1, 2010, until November 30, 2011.

In the project at Utica, the CCC/USDA is cooperating with multiple state and federal agencies to remove carbon tetrachloride contamination from a shallow aquifer underlying the town and to provide supplemental treated groundwater for use in the restoration of a nearby wetlands area. Argonne National Laboratory has assisted the CCC/USDA by providing technical oversight for the aquifer restoration effort and facilities during this review period.

This document presents overviews of the aquifer restoration facilities (Section 2) and system operations (Section 3), then describes groundwater production results (Section 4); groundwater treatment results (Section 5); and associated groundwater monitoring, system modifications, and costs during the review period (Section 6). Section 7 summarizes the present year of operation. Performance in earlier review periods was reported previously (Argonne 2005, 2006, 2008, 2009, 2010, 2011a). 


\section{Overview of the Aquifer Restoration Facilities at Utica}

The principal components of the groundwater restoration systems at Utica are shown in Figure 2.1. The facilities consist of two main operating units, as described below. The facilities include four groundwater extraction (GWEX) wells. Table 2.1 summarizes construction details for these wells.

\subsection{Wells GWEX1-GWEX3 and the Spray Irrigation Treatment Units}

Extraction wells GWEX1-GWEX3, located in the northern portion of the town, are used to extract contaminated groundwater from the upgradient portion of the contaminant plume. These wells are linked by a distribution system that selectively carries untreated groundwater to either of two discharge points in the northern and southern subbasins of the North Lake Basin Wildlife Management Area (Figure 2.1). At each discharge point, the water is treated to remove carbon tetrachloride by using a custom spray irrigation treatment unit (Figure 2.2). The three extraction wells are operated simultaneously to maintain a critical operating pressure at each treatment unit.

Wells GWEX1-GWEX3 are operated intermittently during the year, subject to local weather conditions and in consultation with the Nebraska Game and Parks Commission (NGPC). The NGPC owns most of the property occupied by the wetlands and has administrative and technical responsibility for management of the wildlife area.

\subsection{Well GWEX4 and the Conventional Air Stripper}

Extraction well GWEX4 is located near the downgradient toe of the carbon tetrachloride plume and is operated continuously as a containment well. Groundwater produced from GWEX4 is treated by using a conventional (shallow-tray) air stripping technique, and the effluent is discharged to the surface for reinfiltration into the shallow Utica aquifer. 


\subsection{Monitoring Well Network}

A network of seven permanent monitoring points has been established at Utica (Figure 2.1). Wells SB48, SB71, and SB72 were constructed during the early phases of the investigations. These wells were intended primarily for the measurement of groundwater levels; they do not penetrate the more contaminated zones of the groundwater column identified in detailed vertical-profile sampling (Argonne 2000, 2003, 2011b). To improve monitoring coverage, additional wells MW1-MW4 were installed at strategic locations along the plume migration pathway in August 2005.

TABLE 2.1 Summary of Construction Details for GWEX Wells at Utica.

\begin{tabular}{ccccc}
\hline & \multicolumn{3}{c}{ Depth (ft BGL) } & \\
\cline { 2 - 4 } Well & $\begin{array}{c}\text { Total } \\
\text { Depth }\end{array}$ & $\begin{array}{c}\text { Screen } \\
\text { Interval }\end{array}$ & $\begin{array}{c}\text { Gravel } \\
\text { Pack } \\
\text { Interval }\end{array}$ & $\begin{array}{c}\text { Casing } \\
\text { Diameter } \\
\text { (in.) }\end{array}$ \\
\hline GWEX1 & 132 & $106-126$ & $97-132$ & 8 \\
GWEX2 & 148 & $110-145$ & $106-148$ & 8 \\
GWEX3 & 146 & $105-140$ & $101-146$ & 8 \\
GWEX4 & 150 & $115-145$ & $110-150$ & 6 \\
\hline
\end{tabular}




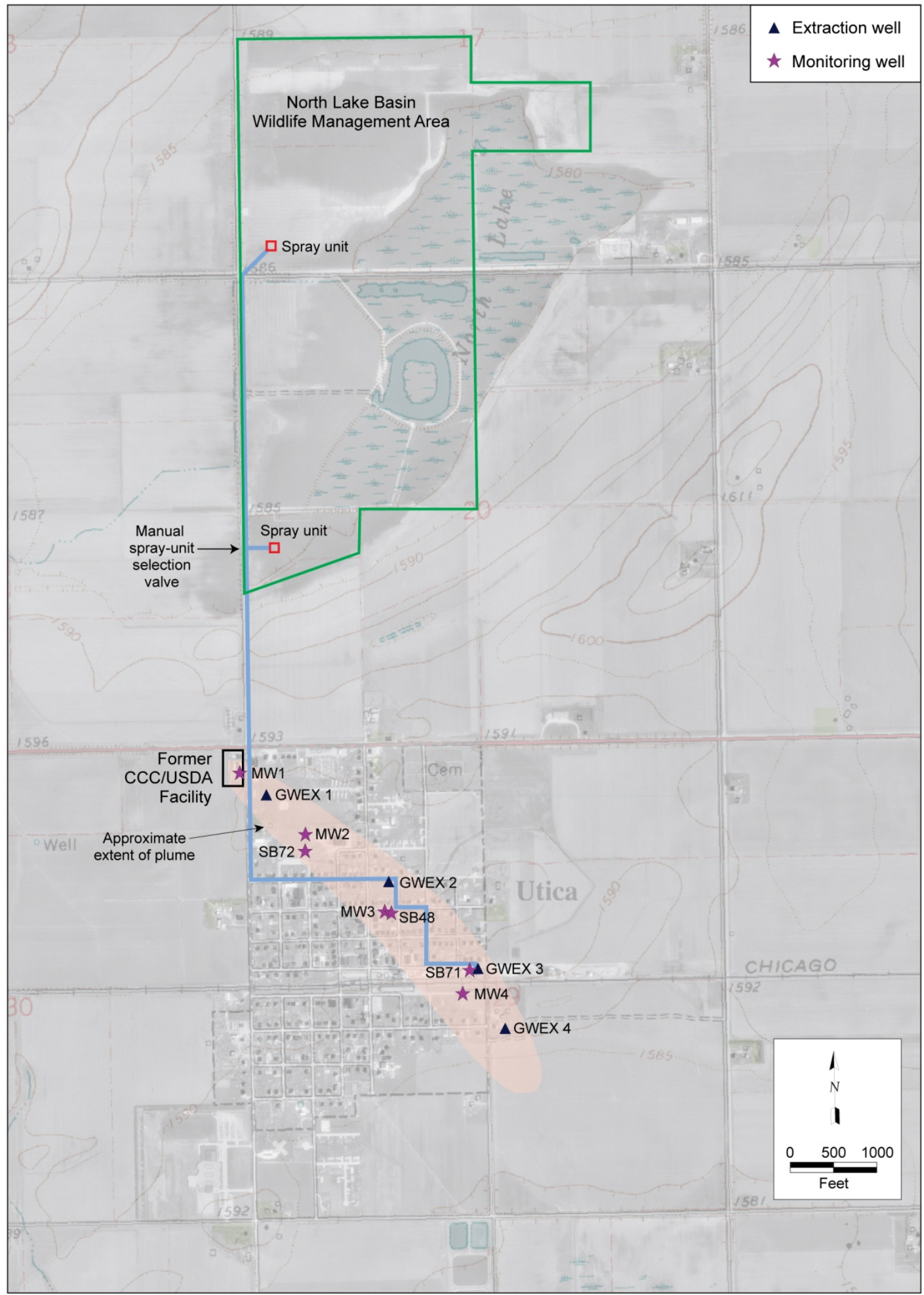

FIGURE 2.1 Locations of the restoration facilities, contaminant plume, and permanent monitoring wells at Utica. 


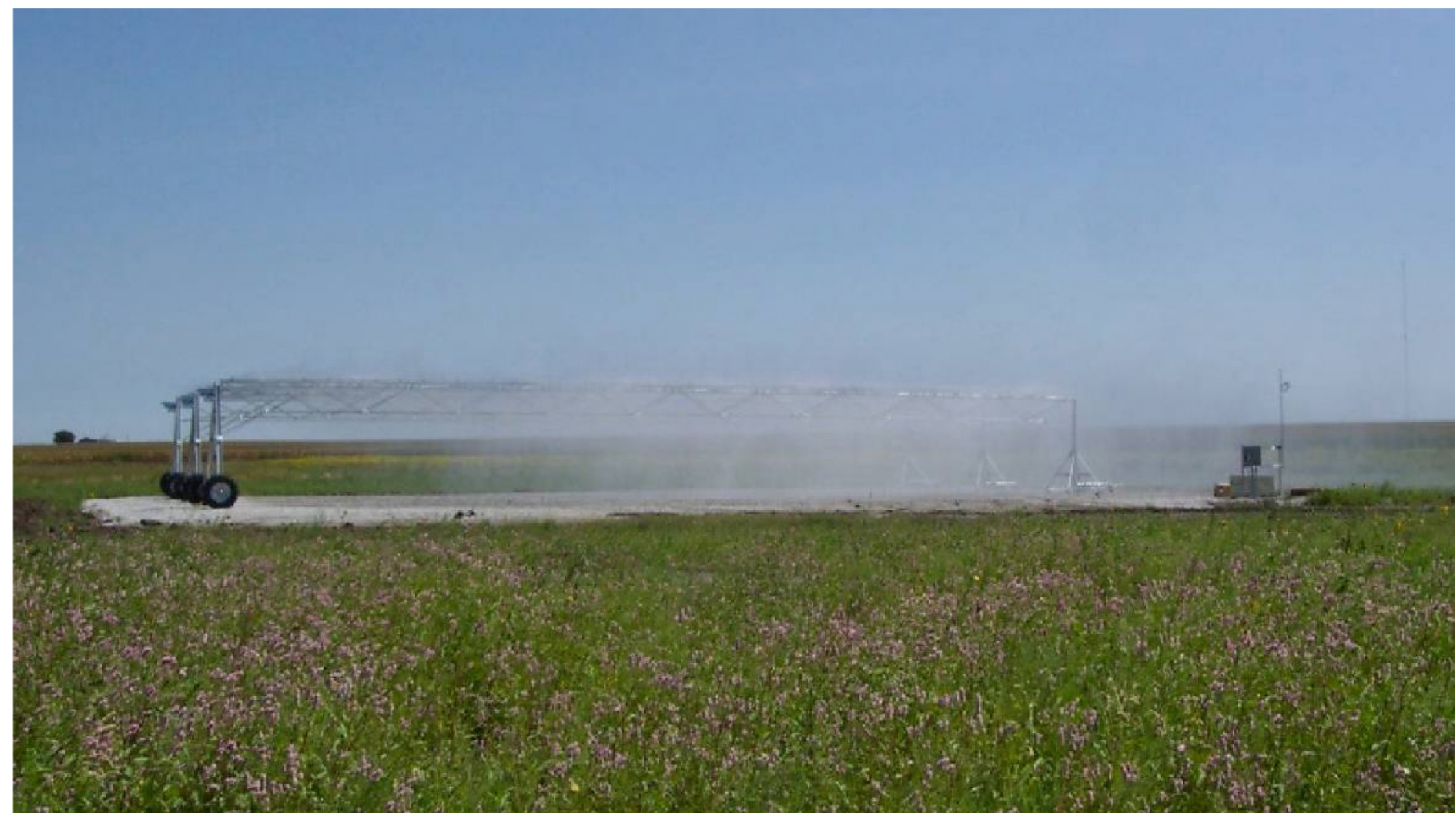

FIGURE 2.2 Spray irrigation unit in operation at Utica. 


\section{Overview of System Operations}

The groundwater restoration program at Utica is conducted in accordance with a National Pollutant Discharge Elimination System (NPDES) permit (No. NE0137456) originally granted by the State of Nebraska, Department of Environmental Quality (NDEQ), for the 5-yr period

October 1, 2004, to September 30, 2009. In accord with NPDES requirements, an application for renewal of the permit was submitted to the NDEQ by the CCC/USDA in spring 2009. On September 28, 2009, the CCC/USDA received notice from the NDEQ that the term of the existing NPDES permit had been extended indefinitely and that the requirements of the original NPDES permit remain valid and in force. To date, no further communications have been received from the NDEQ concerning the permit.

\subsection{Operation of Wells GWEX1-GWEX3 and the Spray Irrigation Treatment Units}

Wells GWEX1-GWEX3 and the spray irrigation treatment units operated intermittently, under automated control, during 8 of the 12 months in the current review period (December 2010-November 2011). The treated groundwater was discharged to the south wetlands subbasin during the spring and early summer (March through July) and to the north subbasin in the late summer and fall (August-October), at the request of the NGPC.

Wells GWEX1-GWEX3 and the spray treatment units were not operated in JanuaryMarch 2011, because generally low $\left(<45^{\circ} \mathrm{F}\right)$ winter and early spring temperatures precluded the effective use of the spray treatment process during this period.

The operation of wells GWEX1-GWEX3 was suspended on October 25, 2011, to facilitate maintenance of the pipeline valves and automated valve actuators that control the flow of (untreated) groundwater from these wells to the spray irrigation treatment units at the north subbasin. Wells GWEX1-GWEX3 and the spray treatment units remained out of service through the end of the review period, pending completion of these repairs.

\subsection{Operation of Well GWEX4 and the Conventional Air Stripper}

Well GWEX4 and the associated air stripper were operated during nine months of the current review period. 
Well GWEX4 was taken out of service during the previous review period (in May 2010) to address recurring problems associated with sand production, fouling of the totalizing flow meter used to document the well's performance, and declining flow rates following repairs to the well in October 2009. In August 2010, the pump and riser pipe were removed from GWEX4, and a downhole camera survey of the well was conducted. No damage to either the casing or screen was immediately apparent; however, thick deposits of a soft material — possibly algae or bacteria - in the deeper parts of the well obscured the screen and prevented detailed inspection.

The well was reconditioned by air-lift pumping in early 2011, and the existing riser pipe and pump were reinstalled. Operation of well GWEX4 resumed on March 23, 2011. A new totalizing flow meter was installed at this time to monitor the GWEX4 performance. Well GWEX4 operated continuously, without further maintenance, through the remainder of the current review period. 


\section{Groundwater Production Results}

The volumes of groundwater extracted from the Utica aquifer, treated, and discharged during the current review period are summarized in Table 4.1. Production during the $7 \mathrm{yr}$ of system operation to date is summarized in Section 7.

\subsection{Production by Wells GWEX1-GWEX3}

Wells GWEX1-GWEX3 are equipped with electronically controlled pump drive units linked to digital flow meters that automatically and continuously adjust the flow from each well to maintain user-specified pumping rates. During this review period, the programmed flow rates for these wells were as follows:

- GWEX1, 50 gpm

- GWEX2, 200 gpm

- GWEX3, 125 gpm

The selected rates were achieved, within $\pm 0.5 \mathrm{gpm}$, throughout the review period (Table 4.2).

Wells GWEX1-GWEX3 were pumped for approximately 3,223 hr during the review period, and they discharged approximately 72.5 million gallons (223 acre-feet) of treated water to the North Lake Basin wetlands. The current production is comparable to that achieved in the previous reporting period (approximately 71.9 million gallons; Argonne 2011a), but it is approximately $20 \%$ less than the maximum seasonal production total achieved by these wells to date (approximately 91 million gallons during the 2006-2007 review period; see Section 7). The treated groundwater was distributed to both the southern (approximately 57\% of total production) and northern wetlands subbasins during the current review period, at the request of the NGPC.

In the current review period, the spray irrigation treatment systems were not operated during December 2010-February 2011; in addition, these systems received limited use in March 2011 , because seasonally cold weather prohibited the effective use of the spray irrigation 
treatment process. Wells GWEX1-GWEX3 and the spray treatment units were shut down on October 25, 2011, to permit repair of the pipeline valves and associated actuators that control groundwater flow to the north subbasin. Wells GWEX1-GWEX3 were not restarted during the remainder of the review period because of continued maintenance at the northern spray pad.

\subsection{Production by Well GWEX4}

As noted in Section 3.2, well GWEX4 was removed from service in May 2010 (during the previous review period) to address declining pumping rates (Argonne 2011a). The well was returned to service on March 23, 2011, and operated continuously for the remainder of the current review period. The volume of groundwater produced in any one complete month of pumping (Table 4.1) ranged from about 2.0 million gallons to 3.1 million gallons. Instantaneous flow rates determined at the wellhead ranged from approximately $72.3 \mathrm{gpm}$ (shortly after pumping was resumed) to $53.6 \mathrm{gpm}$ (at the end of November), again showing a slow decline during the review period.

Approximately 21.7 million gallons (66.5 acre-feet) of groundwater was treated and discharged by well GWEX4 during the review period, at an average (365-day) pumping rate of $41.2 \mathrm{gpm}$. The average flow rate from GWEX4 was $59.5 \mathrm{gpm}$ (Table 4.2) during the 253 days during the review period on which it actually operated. The total production and average pumping rates observed during the current review period reflect a significant increase relative to the performance achieved by GWEX4 in the previous review period (2009-2010; approximately 11.4 million gallons produced, at average 365-day and operational pumping rates of $21.6 \mathrm{gpm}$ and $52.3 \mathrm{gpm}$, respectively). 
TABLE 4.1 GWEX operation and groundwater production data in December 2010-November 2011.

\begin{tabular}{|c|c|c|c|c|c|c|c|c|}
\hline \multirow[b]{3}{*}{ Month } & \multicolumn{4}{|c|}{ Wells GWEX1-GWEX3 (gal) } & \multirow{2}{*}{\multicolumn{2}{|c|}{$\begin{array}{c}\text { Volume Discharged to } \\
\text { Wetlands }^{c} \text { (gal) }\end{array}$}} & \multicolumn{2}{|c|}{ GWEX4 } \\
\hline & \multicolumn{3}{|c|}{ Groundwater Produced $^{\mathrm{a}}$} & \multirow{2}{*}{$\begin{array}{l}\text { Operating } \\
\text { Time }^{\mathrm{b}} \\
(\mathrm{hr})\end{array}$} & & & \multirow{2}{*}{$\begin{array}{l}\text { Groundwater } \\
\text { Produced } \\
\text { (gal) }\end{array}$} & \multirow{2}{*}{$\begin{array}{c}\text { Operating } \\
\text { Time } \\
\text { (days) }\end{array}$} \\
\hline & GWEX1 & GWEX2 & GWEX3 & & North & South & & \\
\hline Dec 10 & $-d$ & - & - & - & - & - & - & - \\
\hline Jan 11 & - & - & - & - & - & - & - & - \\
\hline Feb 11 & - & - & - & - & - & - & - & - \\
\hline Mar 11 & 292,200 & $1,185,200$ & 727,400 & 98.0 & - & $2,204,800$ & 685,600 & 9 \\
\hline Apr 11 & 553,900 & $2,232,700$ & $1,386,900$ & 185.5 & - & $4,173,500$ & $3,144,700$ & 30 \\
\hline May 11 & $1,240,800$ & $5,006,800$ & $3,123,200$ & 416.5 & - & $9,370,800$ & $3,045,856$ & 31 \\
\hline Jun 11 & $1,611,800$ & $6,507,100$ & $4,057,700$ & 541.2 & - & $12,176,600$ & $1,984,276$ & 30 \\
\hline Jul 11 & $1,757,700$ & $7,074,400$ & $4,414,000$ & 588.7 & - & $13,246,100$ & $2,848,668$ & 31 \\
\hline Aug 11 & $1,404,600$ & $5,653,100$ & $3,425,700$ & 465.9 & $10,483,400$ & - & $2,569,772$ & 31 \\
\hline Sep 11 & $1,423,700$ & $5,749,500$ & $3,686,000$ & 482.6 & $10,859,200$ & - & $2,531,380$ & 30 \\
\hline Oct 11 & $1,339,500$ & $5,327,500$ & $3,333,000$ & 444.4 & $10,000,000$ & - & $2,530,272$ & 31 \\
\hline Nov 11 & - & - & - & - & - & - & $2,335,292$ & 30 \\
\hline \multicolumn{9}{|l|}{ Column } \\
\hline Totals & $9,624,200$ & $38,736,300$ & $24,153,900$ & 3,223 & $31,342,600$ & $41,171,800$ & $21,675,816$ & 253 \\
\hline
\end{tabular}

a Combined total production from wells GWEX1-GWEX4: 94,190,216 gal.

b Wells GWEX1-GWEX3 operate simultaneously.

c Total production to wetlands: $72,514,400$ gal.

d Unit not in operation. 
Utica Annual Review, December 2010-November 2011

Version 00, 01/05/12

TABLE 4.2 Comparison of actual well production rates and target rates.

\begin{tabular}{ccc}
\hline & \multicolumn{2}{c}{ Pumping Rate (gpm) } \\
\cline { 2 - 3 } Well & Target & Actual (Net Average) ${ }^{\mathrm{a}}$ \\
& & \\
\hline & & 49.8 \\
GWEX1 & 50 & 200.3 \\
GWEX2 & 200 & 124.9 \\
GWEX3 & 125 & 59.5 \\
GWEX4 & $60-65$ & \\
\hline
\end{tabular}

a Average for actual periods of operation. 


\section{Groundwater Treatment Results}

Treated groundwater at Utica is discharged under NPDES permit No. NE0137456, issued by the NDEQ on October 1, 2004. The original (5-yr) term of this permit has been indefinitely extended by the NDEQ.

To comply with the NPDES requirements, samples of treated groundwater are collected monthly

- At the outlet of the air stripping unit at GWEX4 and

- From the spray discharge at each of the irrigation treatment units (during months of operation).

The samples are analyzed to determine the residual concentrations of carbon tetrachloride in the treated groundwater and the $\mathrm{pH}$ of the effluent. The results of these analyses are reported to the NDEQ quarterly.

The discharges of treated groundwater at Utica are considered by the NDEQ to contribute to the surface waters of the state. On this basis, the NDEQ has specified the following compliance limits for the outfall from each treatment unit:

- A target maximum residual carbon tetrachloride concentration of $44.2 \mu \mathrm{g} / \mathrm{L}$

- $\quad$ An acceptable $\mathrm{pH}$ range of 6.5 to 9.0

In conjunction with the compliance sampling, Argonne collects monthly samples of the untreated groundwater from each extraction well. The samples are analyzed for volatile organic compounds (VOCs) to enable estimation of the following:

- Carbon tetrachloride removal efficiencies for the treatment units

- Quantities of carbon tetrachloride removed from the contaminated aquifer 
The results of the sampling and analyses during the review period are summarized in Tables 5.1 and 5.2.

\subsection{Results for Wells GWEX1-GWEX3, with Treatment by Spray Irrigation}

The concentrations of carbon tetrachloride found in the untreated groundwater from extraction wells GWEX2 and GWEX3 were highest upon initial startup of the wells in March 2011 (following shutdown for the preceding winter). The observed concentrations decreased to lower but relatively stable levels in April-August, and then declined further in September and October (Table 5.1). Carbon tetrachloride concentrations at GWEX2 ranged from $15 \mu \mathrm{g} / \mathrm{L}$ to $40 \mu \mathrm{g} / \mathrm{L}$, while at GWEX3 the levels ranged from $14 \mu \mathrm{g} / \mathrm{L}$ to $41 \mu \mathrm{g} / \mathrm{L}$.

Observed carbon tetrachloride levels at upgradient extraction well GWEX1 increased from $13 \mu \mathrm{g} / \mathrm{L}$ at the onset of pumping in March to a maximum of $57 \mu \mathrm{g} / \mathrm{L}$ in August, then decreased to $34 \mu \mathrm{g} / \mathrm{L}$ in October. The observed concentrations at GWEX1 showed no apparent correlation to the concentrations observed at GWEX2 and GWEX3.

The groundwater produced from wells GWEX1-GWEX3 is combined into a single stream for conveyance to the wetlands via a common pipeline. This combined flow is also sampled monthly as an indicator of the weighted average concentration of carbon tetrachloride in the untreated groundwater supplied to the spray irrigation treatment units. The measured concentrations in the combined flow varied from $18 \mu \mathrm{g} / \mathrm{L}$ to $35 \mu \mathrm{g} / \mathrm{L}$ during the current monitoring period. The temporal variations in concentration observed in the combined flow stream generally mirrored those observed at wells GWEX2 and GWEX3, which together contribute approximately $87 \%$ of the total discharge from the extraction well system.

Treated groundwater sprayed from the irrigation units is collected for analysis at the following four locations at the treatment site during each sampling event:

- Beneath the center point of the "west" irrigation span

- Beneath the center point of the "center" irrigation span

- Beneath the center point of the "east" irrigation span 
- At a fourth location visually chosen to reflect the estimated site of maximum spray outfall ("max" value; position varying from month to month; based on prevailing wind and spray conditions at the time of sampling)

The results summarized in Table 5.1 show that the concentrations of all spray samples collected during the review period were below (1) the maximum contaminant level (MCL) of $5.0 \mu \mathrm{g} / \mathrm{L}$ promulgated by the U.S. Environmental Protection Agency (EPA) for carbon tetrachloride in drinking water and (2) the method quantitation limit $(1.0 \mu \mathrm{g} / \mathrm{L})$ of the standard laboratory procedures used for the groundwater analyses (purge-and-trap sample preparation with analysis on a gas chromatograph-mass spectrometer system; EPA Methods 5030B and 8260B). The maximum carbon tetrachloride level identified for a single sample of spray discharged from the irrigation treatment units was approximately $0.7 \mu \mathrm{g} / \mathrm{L}$. The average concentration of carbon tetrachloride in the treated groundwater discharged to the wetlands was $<0.1 \mu \mathrm{g} / \mathrm{L}$. The concentrations of carbon tetrachloride in all spray samples were below the maximum target concentration $(44.2 \mu \mathrm{g} / \mathrm{L})$ allowed under the NPDES permit, by roughly two orders of magnitude.

The results of the groundwater and spray sample analyses suggest the following minimum carbon tetrachloride removal efficiency values for the spray irrigation treatment process:

- More than $97 \%$ (based on data for individual samples)

- More than $99 \%$ (based on the average concentration delivered to the wetlands during the review period)

The results of $\mathrm{pH}$ measurements recorded for samples of the treated spray discharge are in Table 5.2. In all cases, the observed $\mathrm{pH}$ levels ( 7.45 to 8.50 ) were within the acceptable range (6.5 to 9.0) specified under the NPDES permit.

\subsection{Results for Well GWEX4, with Treatment by Air Stripping}

Low concentrations of carbon tetrachloride were detected in the untreated groundwater produced by GWEX4 (3.8-8.6 $\mu \mathrm{g} / \mathrm{L}$; Table 5.1) for the 9 months in which this well operated during the current review period (March to November 2011). The carbon tetrachloride 
concentration in the untreated groundwater dropped below the MCL of $5.0 \mu \mathrm{g} / \mathrm{L}$ in July, October, and November but exceeded the MCL in August and September 2011. Carbon tetrachloride was not detected in the effluent from the air stripping unit throughout the review period (at a laboratory method detection limit of $0.1 \mu \mathrm{g} / \mathrm{L}$ ), indicating a carbon tetrachloride removal efficiency of $>99 \%$ for this process. Measured $\mathrm{pH}$ levels in all samples of the air stripper effluent (7.10 to 8.04; Table 5.2) were within the acceptable range (6.5 to 9.0) specified under the NPDES permit.

\subsection{Estimated Removal of Carbon Tetrachloride from the Utica Aquifer}

The groundwater production and carbon tetrachloride concentration data presented in Table 4.1 and Table 5.1, respectively, can be used to estimate the total quantity of carbon tetrachloride extracted by wells GWEX1-GWEX4 from December 1, 2010, to November 30, 2011. The results of these calculations, summarized in Table 5.3, indicate that approximately $7.0 \mathrm{~kg}$ ( $1.1 \mathrm{gal})$ of carbon tetrachloride was removed from the Utica aquifer during the present review period. In the previous period (December 2009-November 2010), approximately $8.7 \mathrm{~kg}$ (1.5 gal) of carbon tetrachloride was removed. These values are significantly lower than the quantities of carbon tetrachloride recovered annually from the Utica aquifer during the first $3 \mathrm{yr}$ of operation of the remedial systems (23-34 kg/yr in 2004-2007), but they are similar to the annual rates of removal observed since the 2007-2008 review period (Table 5.4).

The reduced quantities of carbon tetrachloride recovered from the Utica aquifer in the more recent review periods reflect decreasing trends in the concentrations of carbon tetrachloride observed in the groundwater produced by wells GWEX2-GWEX4 (see Section 5.4), as well as somewhat lower annual groundwater production totals achieved in the later periods in comparison to the peak production years of 2005-2006 and 2006-2007 (Table 5.4). No decrease in the volumetric throughput (when operating) or contaminant removal efficiency of the groundwater treatment systems was observed during the current period.

\subsection{Sampling of Monitoring Wells and Apparent Carbon Tetrachloride Concentration Trends in the Utica Groundwater}

Table 5.5 summarizes construction data for the monitoring wells, as well as the results of groundwater sampling and analyses for VOCs during the current review period. In accord with 
recommendations presented in the Utica 5-yr performance summary (Argonne 2011b), the quarterly sampling of shallow monitoring wells SB48 and SB71 was discontinued after the August 2011 sampling event. Complete monitoring data for wells MW1-MW4, since sampling at these points began in September 2005, are depicted in Figure 5.1. Figures 5.2-5.5 summarize the carbon tetrachloride concentrations measured at GWEX1-GWEX4, respectively, since the routine operation and sampling of these wells began in November 2004.

Except for MW1, the carbon tetrachloride concentrations at all of the monitoring wells (Table 5.5 and Figure 5.1) have been relatively stable, with no persistent rising or falling trends. Carbon tetrachloride concentrations at MW1 have been consistently greater than those at downgradient monitoring wells MW2-MW4 (Figures 2.1 and 5.1). Concentrations at MW1 increased to a maximum in June-October 2007 (Figure 5.1), then decreased significantly from October 2007 to November 2008 and finally remained relatively stable $(100-131 \mu \mathrm{g} / \mathrm{L})$ during the 2008-2009 review period. The carbon tetrachloride concentrations at MW1 have varied widely since September 2009, showing no clear rising or falling trend. The carbon tetrachloride concentration of $301 \mu \mathrm{g} / \mathrm{L}$ detected at MW1 during the August 2011 groundwater sampling event represents the highest value observed at MW1 since the maximum concentration $(542 \mu \mathrm{g} / \mathrm{L})$ was detected in June 2007. At the end of the current review period (November 2011), however, the identified carbon tetrachloride level at MW1 dropped to the lowest concentration that has been detected at this location $(45 \mu \mathrm{g} / \mathrm{L})$ since the well was first sampled in September 2005. This observation suggests that the brief increase in concentration at well MW1 was a minor event in terms of the mass of carbon tetrachloride.

The higher concentrations at well MW1 over an extended period in 2007-2008 were not reflected by a corresponding increase at GWEX1, just downgradient from MW1. This observation implies that the mass of carbon tetrachloride (as opposed to the concentration) detected at MW1 is quite small. This interpretation is consistent with results of both past and recent vertical profile sampling with the cone penetrometer, which suggested that the occasionally high carbon tetrachloride levels at MW1 are restricted to the shallowest groundwater beneath the former CCC/USDA facility and that the carbon tetrachloride quickly becomes diluted or dispersed with depth and distance downgradient. Wells MW1 and GWEX1 were completed at shallower depths than the downgradient wells for the specific purpose of detecting and intercepting this sporadic influence. 
Wells MW1 and GWEX1 are located, respectively, on and near the former CCC/USDA facility property (Figure 2.1). Together, the data for MW1 and GWEX1 (Figure 5.1 and 5.2) might reflect a localized influx of carbon tetrachloride to the upgradient shallow groundwater, from residual contamination in the soils beneath the former CCC/USDA facility (Argonne 2000, 2003). The stable or decreasing contaminant levels observed at all of the downgradient monitoring wells and GWEX wells demonstrate, however, that (1) GWEX1 is presently operating effectively as an upgradient capture well and (2) the seasonal pumping strategy employed is effectively removing the groundwater contamination and preventing further downgradient expansion of the carbon tetrachloride plume.

The identified carbon tetrachloride concentrations at downgradient extraction wells GWEX2-GWEX4 (Figures 5.3-5.5) have shown a slow decline during the period of record, although short-term variability is apparent within the generally decreasing trend for each well. At GWEX2 and GWEX3, an annual pattern of relatively higher initial concentrations at each well upon seasonal (spring) start-up is apparent, followed by generally declining contaminant levels during periods of continuous operation. In contrast, carbon tetrachloride concentrations at upgradient well GWEX1 (Figures 2.1 and 5.2) have shown no clear long-term trend and appear to increase during seasonal periods of continuous operation. These observed concentration trends are qualitatively consistent with the overall patterns of contaminant reduction identified in the Utica groundwater during the 5-yr performance review, conducted in 2010 (Argonne 2011b).

\subsection{Groundwater Inorganic Geochemistry}

In accord with the original Monitoring Plan for Utica (Argonne 2004), samples of the untreated groundwater from individual extraction wells GWEX1-GWEX4 and the (treated) effluent from the air stripper at GWEX4 were collected annually and submitted for inorganic geochemical analyses, from 2005 through 2010. The results of these analyses documented no significant changes in the geochemistry of the groundwater in association with the extraction, treatment, and discharge of groundwater to the surface near Utica and to the North Lake Basin wetlands during this period. In view of these findings, and in accord with the recommendations presented in the Utica 5-yr performance summary (Argonne 2011b), sampling of the groundwater for inorganic analyses was discontinued in the current review period. 
TABLE 5.1 Analytical results for carbon tetrachloride in untreated groundwater samples and treated effluent samples in December 2010November 2011.

\begin{tabular}{|c|c|c|c|c|c|c|c|c|c|c|c|c|c|c|}
\hline \multirow[b]{3}{*}{ Month } & \multicolumn{14}{|c|}{ Carbon Tetrachloride Concentration ( $\mu \mathrm{g} / \mathrm{L})$} \\
\hline & \multicolumn{4}{|c|}{ GWEX1-GWEX3 Untreated } & \multicolumn{4}{|c|}{ North Spray Unit Effluent } & \multicolumn{4}{|c|}{ South Spray Unit Effluent } & \multirow{2}{*}{$\begin{array}{l}\text { GWEX4 } \\
\text { Untreated }\end{array}$} & \multirow{2}{*}{$\begin{array}{l}\text { Stripper } \\
\text { Effluent }^{d}\end{array}$} \\
\hline & GWEX1 & GWEX2 & GWEX3 & Mixeda & West $^{\mathrm{b}}$ & Center $^{b}$ & East $^{\mathrm{b}}$ & $\operatorname{Max}{ }^{C}$ & West ${ }^{b}$ & Center ${ }^{b}$ & East $^{b}$ & $\operatorname{Max}^{\mathrm{C}}$ & & \\
\hline Dec 10 & $-^{e}$ & - & - & - & $-{ }^{\mathrm{e}}$ & - & - & - & - & - & - & - & - & - \\
\hline Jan 11 & - & - & - & - & - & - & - & - & - & - & - & - & - & - \\
\hline Feb 11 & - & - & - & - & - & - & - & - & - & - & - & - & - & - \\
\hline Mar 11 & 13 & 40 & 41 & 35 & - & - & - & - & $N D^{f}$ & $0.3 \mathrm{Jg}$ & $0.7 \mathrm{~J}$ & ND & 8.6 & ND \\
\hline Apr 11 & 15 & 24 & 25 & 23 & - & - & - & - & ND & $0.3 \mathrm{~J}$ & $0.2 \mathrm{~J}$ & ND & 5.7 & ND \\
\hline May 11 & 26 & 25 & 24 & 26 & - & - & - & - & ND & $0.6 \mathrm{~J}$ & ND & ND & 6.0 & ND \\
\hline Jun 11 & 39 & 24 & 24 & 25 & - & - & - & - & ND & ND & ND & ND & 5.5 & ND \\
\hline Jul 11 & 39 & 19 & 18 & 21 & - & - & - & - & ND & ND & ND & ND & 4.6 & ND \\
\hline Aug 11 & 57 & 29 & 23 & 31 & ND & ND & ND & ND & - & - & - & - & 5.3 & ND \\
\hline Sep 11 & 42 & 21 & 19 & 23 & ND & ND & ND & ND & - & - & - & - & 5.3 & ND \\
\hline Oct 11 & 34 & 15 & 14 & 18 & ND & ND & ND & ND & - & - & - & - & 3.8 & ND \\
\hline Nov 11 & - & - & - & - & - & - & - & - & - & - & - & - & 4.2 & ND \\
\hline
\end{tabular}

a Analytical results for samples from the combined flows of GWEX1-GWEX3. These wells together contribute approximately $87 \%$ of the total discharge from the extraction well system.

b Samples of spray collected below the center point of the respective irrigation span.

c Samples of spray collected at the estimated location of maximum spray outfall.

d The carbon tetrachloride removal efficiency for the GWEX4 air stripping process is $>99 \%$.

e Unit not in operation.

f ND, not detected at a method detection limit of $0.1 \mu \mathrm{g} / \mathrm{L}$.

g Qualifier J indicates an estimated concentration below the quantitation limit of $1.0 \mu \mathrm{g} / \mathrm{L}$ for the purge-and-trap method. 
TABLE 5.2 Values for $\mathrm{pH}$ in untreated groundwater samples and treated effluent samples in December 2010November 2011.

\begin{tabular}{|c|c|c|c|c|c|c|c|c|}
\hline \multirow[b]{3}{*}{ Month } & \multicolumn{8}{|c|}{$\mathrm{pH}$} \\
\hline & \multicolumn{4}{|c|}{ GWEX1-GWEX3 Untreated } & \multirow{2}{*}{$\begin{array}{l}\text { North } \\
\text { Spray } \\
\text { Unit }^{b}\end{array}$} & \multirow{2}{*}{$\begin{array}{l}\text { South } \\
\text { Spray } \\
\text { Unit }^{b}\end{array}$} & \multirow{2}{*}{$\begin{array}{l}\text { GWEX4 } \\
\text { Untreated }\end{array}$} & \multirow{2}{*}{$\begin{array}{l}\text { Stripper } \\
\text { Effluent }\end{array}$} \\
\hline & GWEX1 & GWEX2 & GWEX3 & Mixed $^{a}$ & & & & \\
\hline Dec 10 & $-^{c}$ & - & - & - & _ & - & - & - \\
\hline Jan 11 & - & - & - & - & - & - & - & - \\
\hline Feb 11 & - & - & - & - & - & - & - & - \\
\hline Mar 11 & $7.39-7.53$ & $7.11-7.20$ & $6.97-7.02$ & $6.93-6.95$ & - & $7.89-8.02$ & $6.92-6.96$ & $7.52-7.70$ \\
\hline Apr 11 & $7.62-7.99$ & $7.31-7.41$ & $7.13-7.22$ & $7.11-7.16$ & - & $7.48-7.86$ & $7.40-7.60$ & $7.86-7.91$ \\
\hline May 11 & $7.28-7.50$ & $6.98-7.02$ & 6.85 & 6.85 & - & $7.67-8.03$ & $7.10-7.23$ & $7.74-7.80$ \\
\hline Jun 11 & $7.53-7.75$ & $7.20-7.29$ & $6.99-7.07$ & $6.96-6.99$ & - & $7.56-8.10$ & $7.10-7.32$ & $7.53-7.76$ \\
\hline Jul 11 & $7.26-7.39$ & $7.09-7.14$ & $6.92-6.97$ & $7.49-7.75$ & - & $7.45-8.27$ & $6.79-3.82$ & $7.10-7.51$ \\
\hline Aug 11 & $7.38-7.46$ & $7.11-7.22$ & $6.95-6.99$ & $6.96-6.98$ & $7.93-8.35$ & - & $7.05-7.14$ & $7.32-7.85$ \\
\hline Sep 11 & $7.22-7.43$ & $6.94-7.11$ & $6.78-6.83$ & $7.62-7.90$ & $7.76-8.50$ & - & $7.52-8.04$ & $7.98-8.03$ \\
\hline Oct 11 & $7.17-7.26$ & $7.46-7.48$ & $7.26-7.47$ & 7.31-7.47 & $8.01-8.18$ & - & $7.44-7.67$ & $7.98-8.04$ \\
\hline Nov 11 & $7.16-7.25$ & $6.99-7.06$ & $6.89-6.91$ & $7.30-7.31$ & - & - & $7.10-7.25$ & $7.28-7.40$ \\
\hline
\end{tabular}

a Ranges of values for multiple measurements of the combined flows of GWEX1-GWEX3.

b Ranges of values for spray samples collected at multiple locations at the discharge site.

c Unit not in operation. 
TABLE 5.3 Estimation of carbon tetrachloride removed from the Utica aquifer in December 2010-November 2011. ${ }^{\mathrm{a}}$

\begin{tabular}{|c|c|c|c|c|c|c|c|c|}
\hline \multirow[b]{4}{*}{ Month } & \multicolumn{4}{|c|}{ GWEX1-GWEX3 } & \multicolumn{4}{|c|}{ GWEX4 } \\
\hline & \multirow{2}{*}{\multicolumn{2}{|c|}{ Groundwater Extracted }} & \multicolumn{2}{|c|}{ Carbon Tetrachloride } & & & \multicolumn{2}{|c|}{ Carbon Tetrachloride } \\
\hline & & & & $\begin{array}{c}\text { Calculated } \\
\text { Amount }\end{array}$ & \multicolumn{2}{|c|}{$\begin{array}{c}\text { Groundwater } \\
\text { Extracted }\end{array}$} & \multirow{2}{*}{$\begin{array}{l}\text { Concentration } \\
(\mu \mathrm{g} / \mathrm{L})\end{array}$} & \multirow{2}{*}{$\begin{array}{c}\text { Calculated } \\
\text { Amount } \\
\text { Removed } \\
(\mathrm{kg})\end{array}$} \\
\hline & (gal) & $(\mathrm{L})$ & $(\mu \mathrm{g} / \mathrm{L})$ & $(\mathrm{kg})$ & (gal) & $(\mathrm{L})$ & & \\
\hline Dec 10 & $-^{c}$ & - & - & - & - & - & - & - \\
\hline Jan 11 & - & - & - & - & - & - & - & - \\
\hline Feb 11 & - & - & - & - & - & - & - & - \\
\hline Mar 11 & $2,204,800$ & $8,347,373$ & 34 & 0.28 & 685,600 & $2,595,682$ & 8.6 & 0.02 \\
\hline Apr 11 & $4,173,500$ & $15,800,871$ & 23 & 0.36 & $3,144,700$ & $11,905,834$ & 5.7 & 0.07 \\
\hline May 11 & $9,370,800$ & $35,477,849$ & 26 & 0.92 & $3,045,856$ & $11,531,611$ & 6.0 & 0.07 \\
\hline Jun 11 & $12,176,600$ & $46,100,608$ & 25 & 1.15 & $1,984,276$ & $7,512,469$ & 5.5 & 0.04 \\
\hline Jul 11 & $13,246,100$ & $50,149,735$ & 21 & 1.05 & $2,848,668$ & $10,785,057$ & 4.6 & 0.05 \\
\hline Aug 11 & $10,483,400$ & $39,690,152$ & 31 & 1.23 & $2,569,772$ & $9,729,157$ & 5.3 & 0.05 \\
\hline Sep 11 & $10,859,200$ & $41,112,931$ & 22 & 0.90 & $2,531,380$ & $9,583,805$ & 5.3 & 0.05 \\
\hline Oct 11 & $10,000,000$ & $37,860,000$ & 18 & 0.68 & $2,530,272$ & $9,579,610$ & 3.8 & 0.04 \\
\hline Nov 11 & - & - & - & - & $2,335,292$ & $8,841,416$ & 4.2 & 0.04 \\
\hline TOTAL & & & & 6.59 & & & & 0.43 \\
\hline
\end{tabular}

a Total carbon tetrachloride removed from the aquifer: $7.02 \mathrm{~kg}$.

b Concentration in untreated samples of the combined flow from wells GWEX1-GWEX3.

c Unit not in operation. 
TABLE 5.4 Results of the carbon tetrachloride removal efforts in October 2004-November 2011.

\begin{tabular}{|c|c|c|c|c|c|c|}
\hline \multirow[b]{2}{*}{$\begin{array}{c}\text { Period } \\
\text { of } \\
\text { Operation }\end{array}$} & \multicolumn{3}{|c|}{ GWEX1-GWEX3 } & \multicolumn{3}{|c|}{ GWEX4 } \\
\hline & $\begin{array}{l}\text { Production } \\
\text { (gal) }\end{array}$ & $\begin{array}{c}\text { Average } \\
\text { Carbon } \\
\text { Tetrachloride } \\
\text { Concentration } \\
(\mu \mathrm{g} / \mathrm{L})\end{array}$ & $\begin{array}{l}\text { Carbon } \\
\text { Tetrachloride } \\
\text { Removed } \\
(\mathrm{kg})\end{array}$ & $\begin{array}{l}\text { Production } \\
\text { (gal) }\end{array}$ & $\begin{array}{c}\text { Average } \\
\text { Carbon } \\
\text { Tetrachloride } \\
\text { Concentration } \\
(\mu \mathrm{g} / \mathrm{L})\end{array}$ & $\begin{array}{c}\text { Carbon } \\
\text { Tetrachloride } \\
\text { Removed } \\
(\mathrm{kg})\end{array}$ \\
\hline 2004-2005 & $34,611,960$ & 109 & 14.2 & $31,752,692$ & 75 & 9.0 \\
\hline $2005-2006$ & $84,365,500$ & 99 & 29.2 & $29,584,010$ & 45 & 5.0 \\
\hline 2006-2007 & $90,954,300$ & 65 & 21.8 & $28,320,380$ & 28 & 3.0 \\
\hline $2007-2008$ & $25,675,200$ & 58 & 6.0 & $29,553,474$ & 18 & 2.0 \\
\hline 2008-2009 & $50,633,300$ & 42 & 8.0 & $26,060,159$ & 12 & 1.3 \\
\hline $2009-2010$ & $71,898,100$ & 31 & 8.4 & $11,373,054$ & 8.0 & 0.4 \\
\hline 2010-2011 & $72,514,400$ & 25 & 6.6 & $21,675,816$ & 5.4 & 0.4 \\
\hline TOTAL & $430,652,760$ & & 94.2 & $178,319,585$ & & 21.1 \\
\hline
\end{tabular}


TABLE 5.5 Well construction data and analytical results for carbon tetrachloride in groundwater samples from the permanent monitoring wells.

\begin{tabular}{|c|c|c|c|c|c|c|}
\hline \multirow[b]{3}{*}{ Well } & \multicolumn{2}{|c|}{ Depth (ft BGL) } & & & & \\
\hline & \multirow[b]{2}{*}{ Total } & \multirow{2}{*}{$\begin{array}{l}\text { Screened } \\
\text { Interval }\end{array}$} & \multicolumn{4}{|c|}{ Carbon Tetrachloride ( $\mu \mathrm{g} / \mathrm{L})$} \\
\hline & & & Jan 11 & May 11 & Aug 11 & Nov 11 \\
\hline SB48 & 98.5 & $83.5-93.5$ & $N^{a}$ & ND & ND & $-b$ \\
\hline SB71 & 94.2 & $84-94$ & ND & ND & ND & $-b$ \\
\hline SB72 & 122.3 & 82.6-112.6 & $0.9 \mathrm{Jc}^{\mathrm{c}}$ & $0.9 \mathrm{~J}$ & $0.1 \mathrm{~J}$ & $0.6 \mathrm{~J}$ \\
\hline MW1 & 105 & 85-100 & 113 & 105 & 301 & 45 \\
\hline MW2 & 115 & $90-110$ & 8.3 & 22 & 20 & 14 \\
\hline MW3 & 125 & $100-120$ & 30 & 31 & 33 & 26 \\
\hline MW4 & 125 & $100-120$ & 2.0 & 2.3 & 2.3 & 3.0 \\
\hline
\end{tabular}

a ND, not detected at a method detection limit of $0.1 \mu \mathrm{g} / \mathrm{L}$.

b Per recommendations of the 5-yr evaluation (Argonne 2011b), quarterly sampling of shallow wells SB48 and SB71 was terminated in fall 2011.

c Qualifier J indicates an estimated concentration below the quantitation limit of $1 \mu \mathrm{g} / \mathrm{L}$ for the purge-and-trap method. 


\section{Carbon Tetrachloride Concentrations at Monitoring Wells}

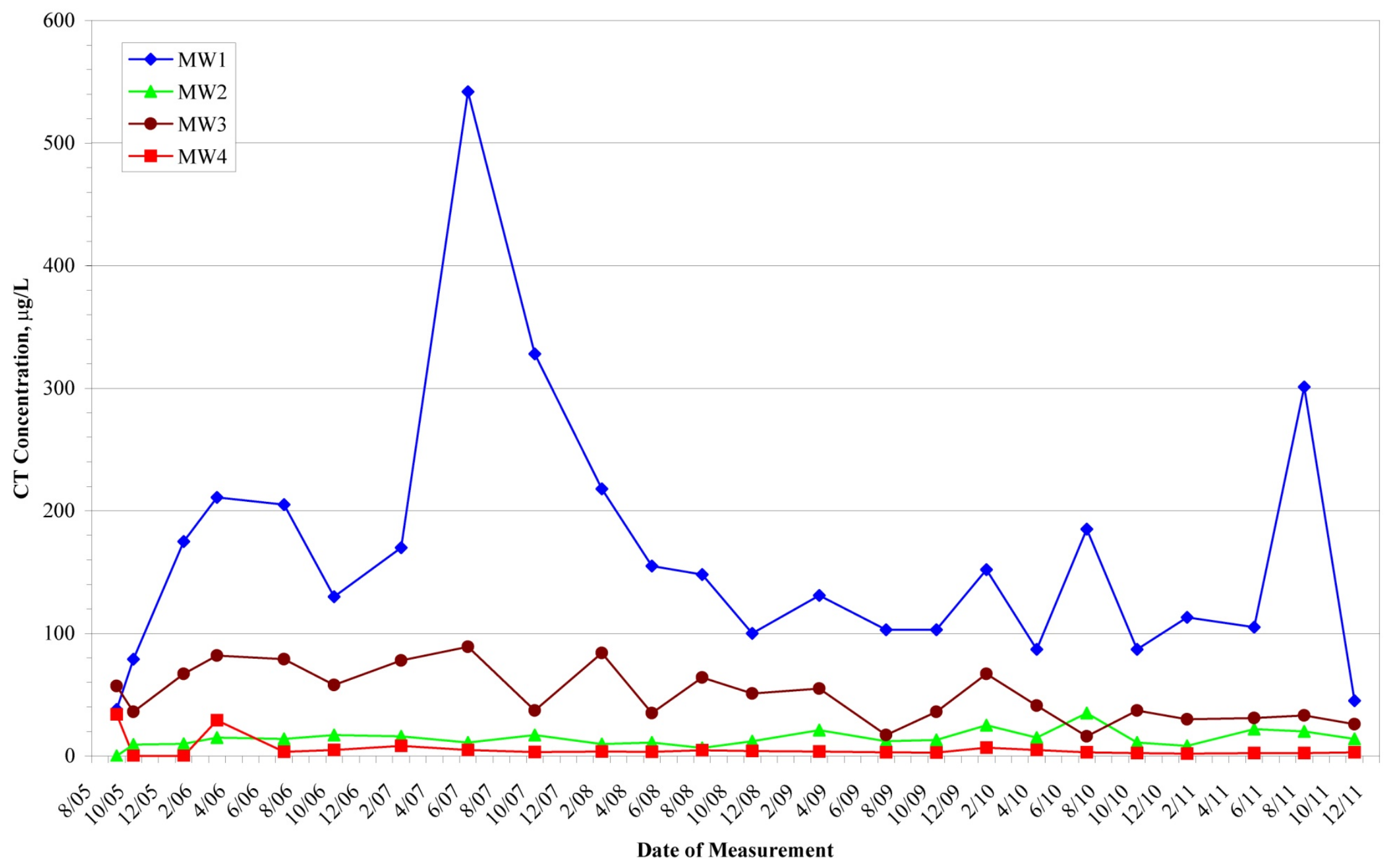

FIGURE 5.1 Carbon tetrachloride concentrations at monitoring wells MW1-MW4, September 2005 to November 2011. 


\section{Carbon Tetrachloride Concentrations at Extraction Well GWEX1}

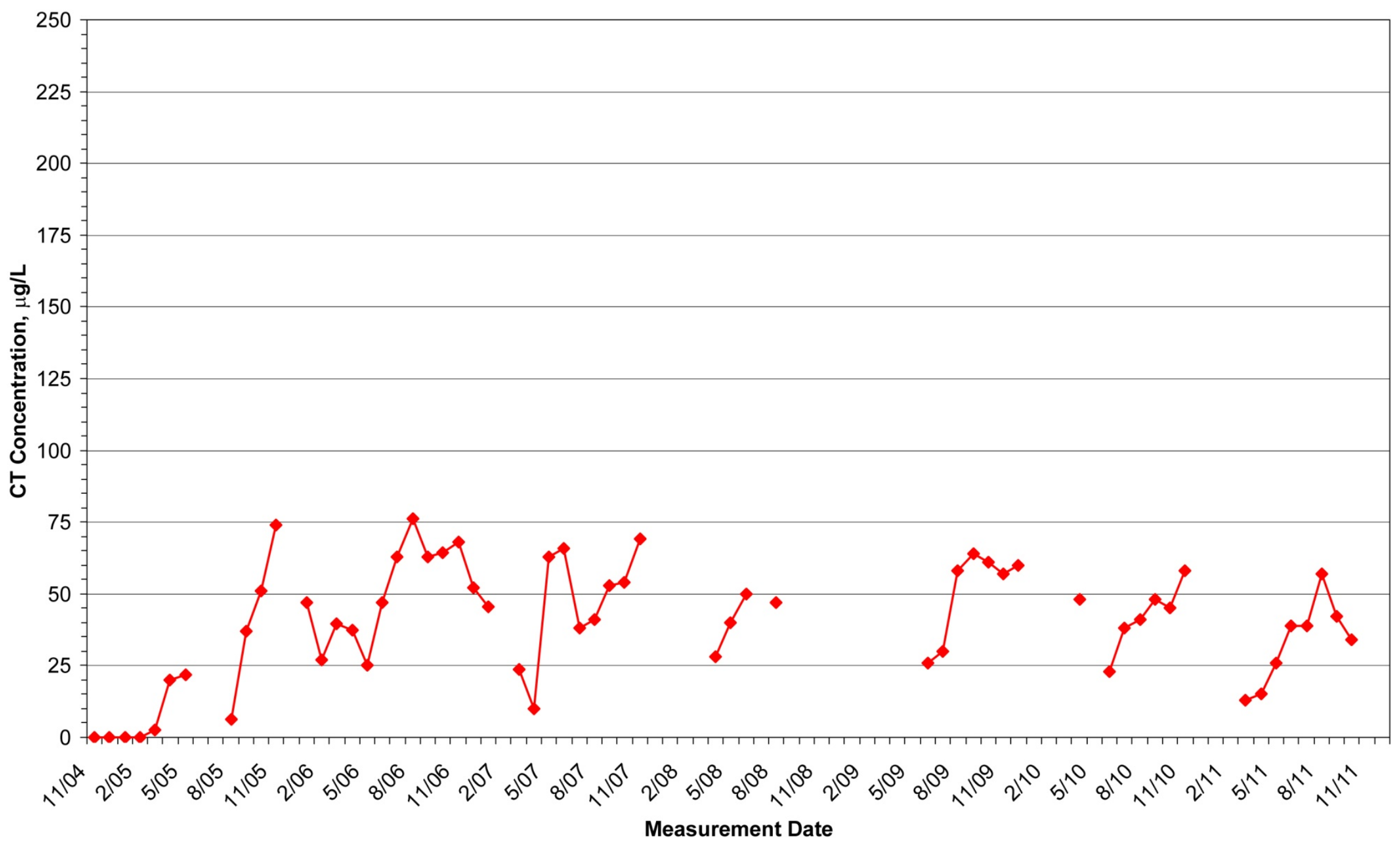

FIGURE 5.2 Carbon tetrachloride concentrations at extraction well GWEX1, November 2004 to November 2011. 


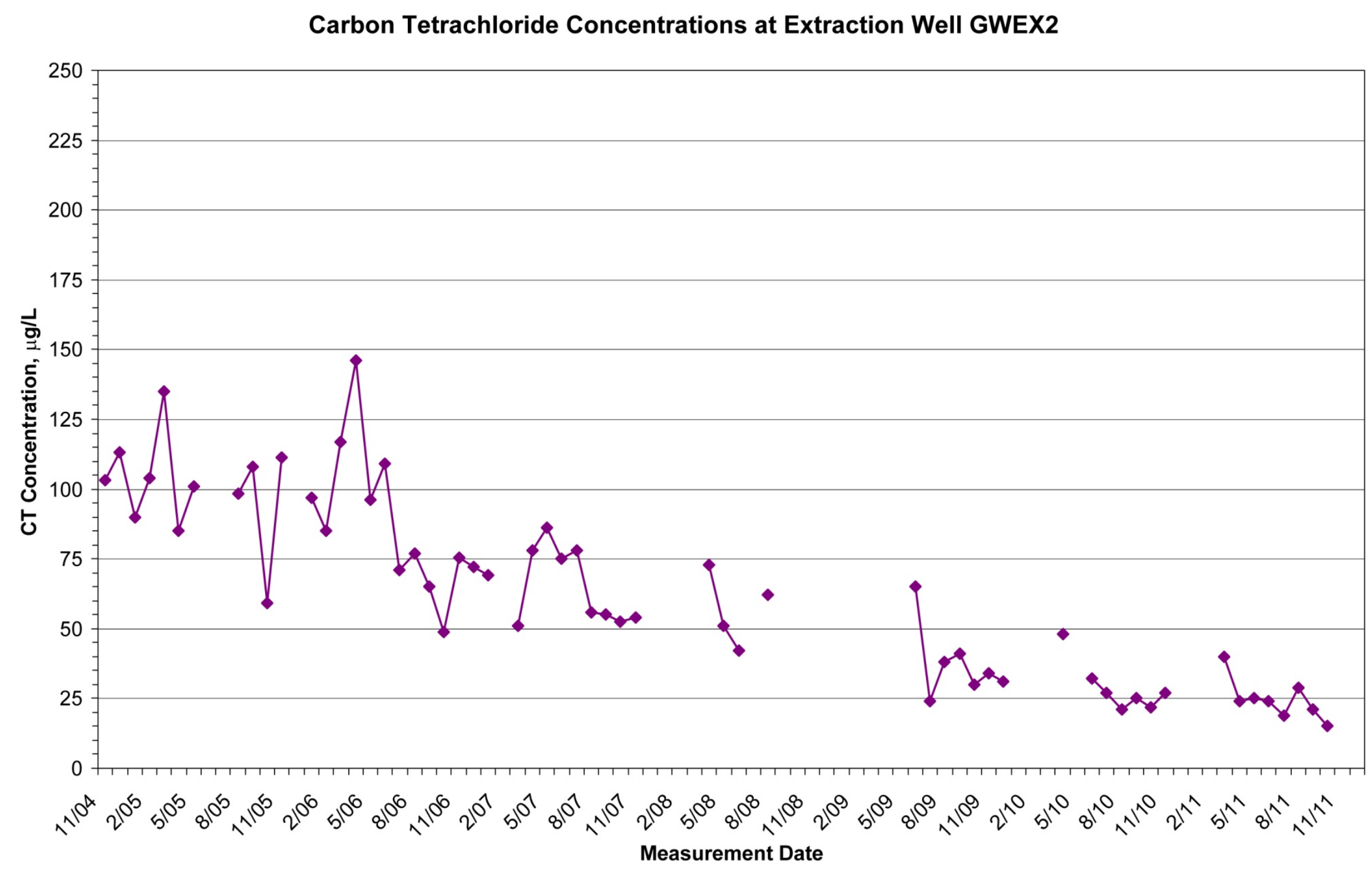

FIGURE 5.3 Carbon tetrachloride concentrations at extraction well GWEX2, November 2004 to November 2011. 


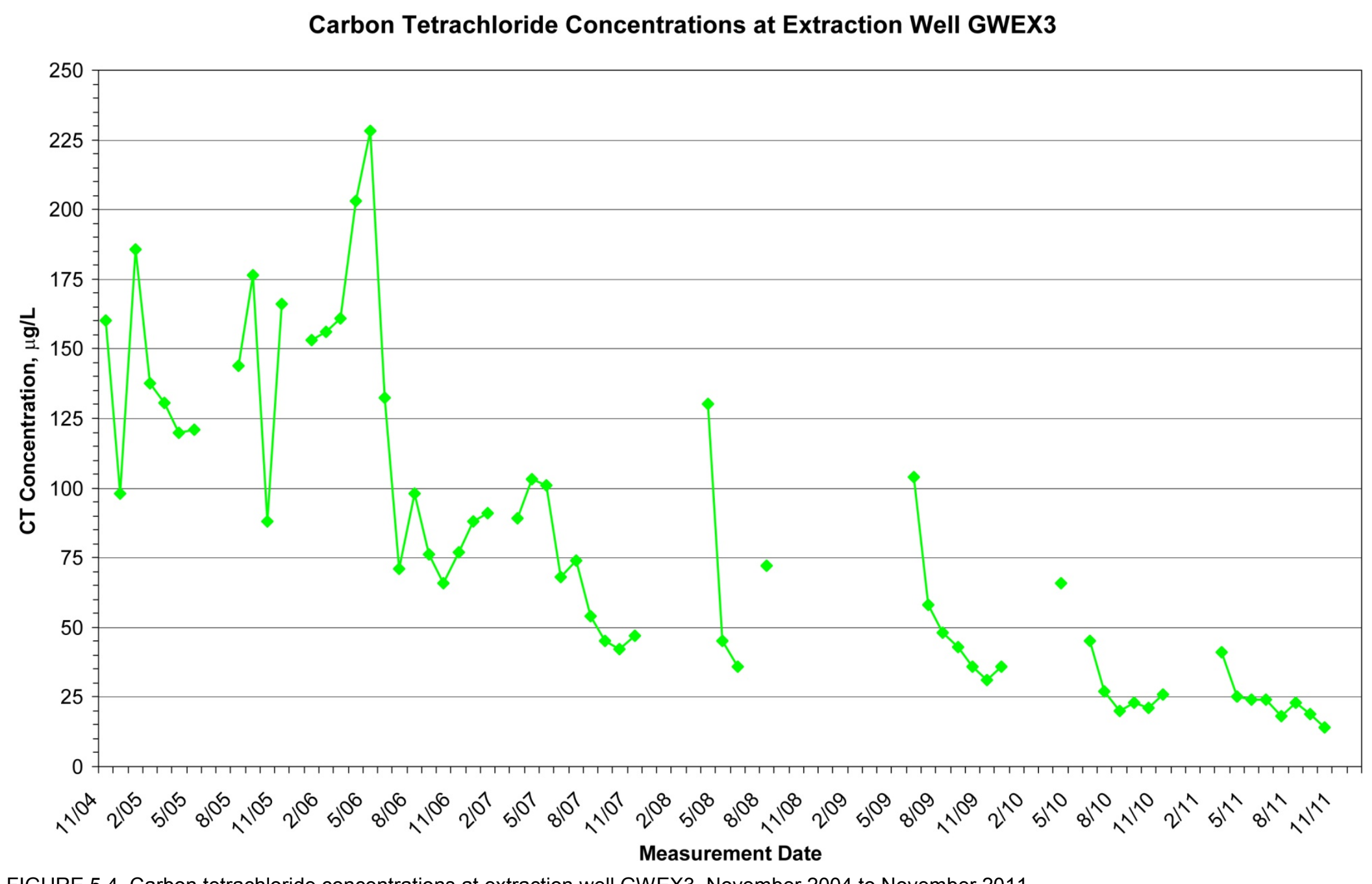

FIGURE 5.4 Carbon tetrachloride concentrations at extraction well GWEX3, November 2004 to November 2011. 
Carbon Tetrachloride Concentrations at Extraction Well GWEX4

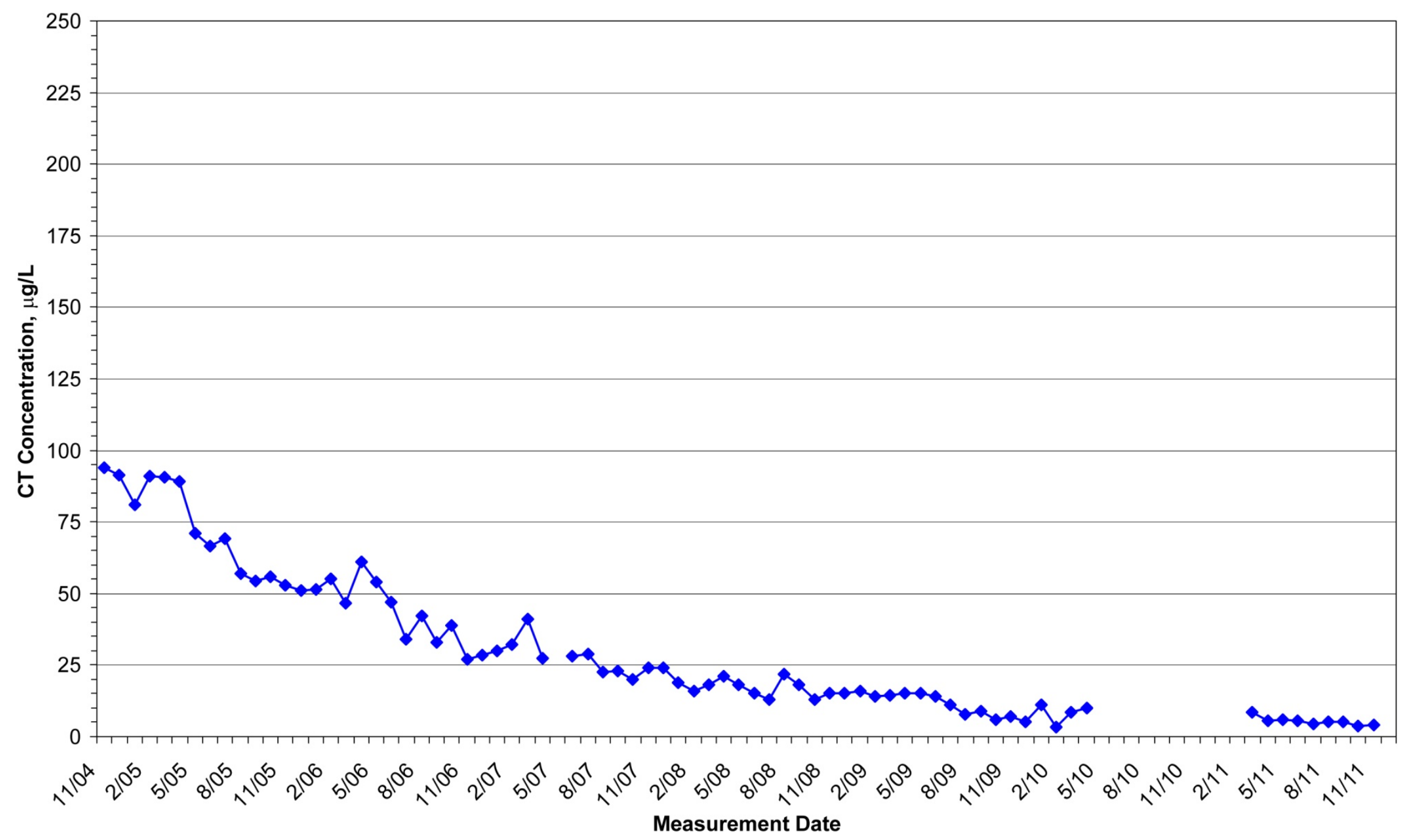

FIGURE 5.5 Carbon tetrachloride concentrations at extraction well GWEX4, November 2004 to November 2011. 


\section{Operation, Maintenance, and System Modifications}

\subsection{Wells GWEX1-GWEX3 and the Spray Irrigation Treatment Units}

No maintenance was required on extraction wells GWEX1-GWEX3 during the current review period; however, an electrical circuit breaker at the control panel for well GWEX3 tripped on several occasions in June and July, requiring that it be manually reset. No obvious cause for the trips was identified, and the well operated normally for the remainder of the review period.

Maintenance and repairs for the spray irrigation units and the groundwater delivery system included the following activities:

- Periodic field inspection of the units and all operating parameters.

- Seasonal mowing along the gravel access roads and pads at the north and south spray treatment sites.

- Repair of a leak in the pipeline carrying groundwater to the wetlands, discovered at one of the inspection manholes along the pipeline upon initial seasonal start-up of the GWEX1-GWEX3 wells in March.

- Removal and reconditioning of the automatic pipeline valve actuators at the north subbasin spray pad. The actuators were damaged by flooding of the (underground) pipeline vault when the north spray pad and hence the existing automatic vault pump were not operated for an extended period. The actuators were removed in the spring; the absence of the actuators does not prevent normal operation of the spray pad under persistent above-freezing conditions. Repairs were completed by fall, but reinstallation of the units had not been completed by the end of the review period (see below).

- Replacement of the pressure sensor on one of the irrigation spans at the north spray treatment site in early September with a spare gauge previously obtained. The replacement corrected faulty pressure readings that had caused 
wells GWEX1-GWEX3 and the treatment system to shut down sporadically in August.

- Temporary reinstallation of the automatic valve actuators (discussed above) at the north spray pad in October. The installation revealed that the associated pipeline butterfly valves were not functioning correctly. Operation of the butterfly valves and actuators is essential for operation of the spray treatment units under the intermittent freezing conditions that typically occur from late fall until early spring. The butterfly valves were removed; however, identical replacement units are no longer available. Modifications to the valve mounts are needed for installation of suitable alternative valves. At the end of the review period, additional modifications to the valve and actuator mountings and the pipeline vault were under consideration. The goal is to prevent possible future damage to these components.

\subsection{Well GWEX4 and the Air Stripping Unit}

In May 2010 (during the previous review period) well GWEX4 was shut down to address problems associated with declining flow rates, sand production, and fouling of the associated flow meter that occurred unexpectedly after replacement of the well's riser pipe and pump in October 2009. In August 2010, the pump and riser pipe were removed, and a downhole camera survey revealed no clear damage to either the well casing or screen; however, thick deposits of a soft (unidentified) material were observed in the deeper parts of the well. Well GWEX4 therefore remained out of service at the end of the previous review period.

Maintenance and repairs for well GWEX4 and the air stripping unit conducted during the current review period included the following:

- The well was reconditioned by air-lift pumping in early 2011. The existing riser pipe and pump were reinstalled, and operation of well GWEX4 was resumed on March 23, 2011.

- A new totalizing flow meter was installed in March, before the well was restarted, to monitor the GWEX4 production. 
- No repairs were required for the air stripping unit at GWEX4; however, the unit was visually inspected and cleaned in conjunction with servicing of the well.

\subsection{Operating and Maintenance Costs}

Operating and maintenance costs for the aquifer restoration systems at Utica are summarized in Table 6.1. These costs include one-time expenses incurred during the current review period (through November 2011), associated with (1) reconditioning of the well and replacement of the flow meter at GWEX4 and (2) refurbishing of the valve actuators at the north wetlands pipeline vault. Additional costs that might be required to return the north vault to service will be reported during the next (2011-2012) review period.

The total operating and maintenance costs for the Utica project during the current review period $(\$ 149,868)$ were only slightly higher than those for December 2009-November 2010 $(\$ 144,785)$ and were the third lowest annual costs incurred during the initial $7 \mathrm{yr}$ of operation (Table 6.1). The routine operating costs for the current review period were the second lowest to date, reflecting a decrease of approximately $6.8 \%$ relative to those for the preceding (2009-2010) period. These savings were offset, however, by the non-routine costs $(\$ 19,196)$ incurred during the current review period. 
TABLE 6.1 Summary of operating and maintenance costs for the Utica restoration project.

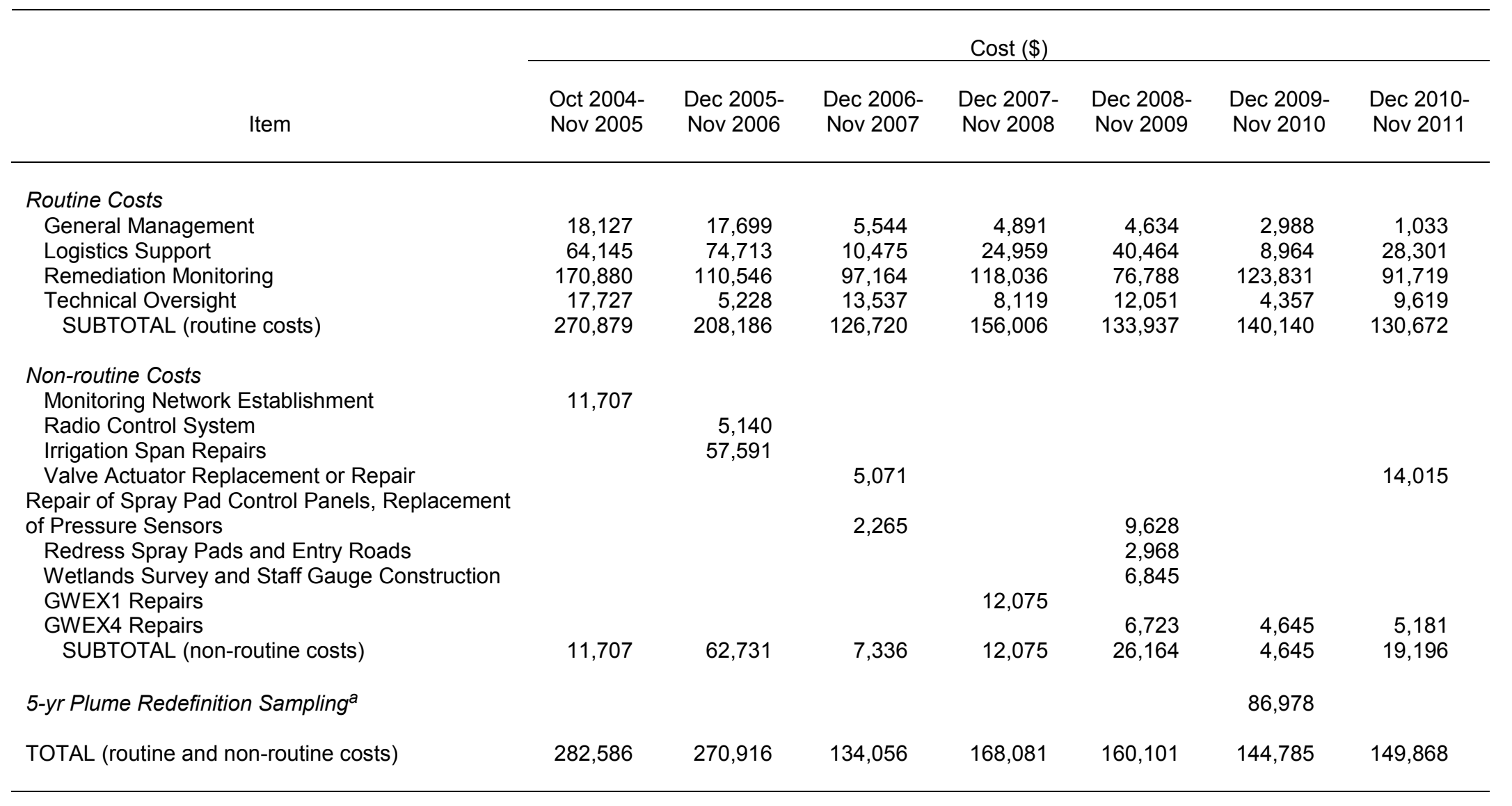

a Costs incurred during the 2009-2010 review period, but not directly associated with the operation or maintenanceof the groundwater restoration systems. 


\section{Summary}

Historical performance data and costs for the first $7 \mathrm{yr}$ of operation of the Utica remedial systems are summarized in Tables 5.4, 7.1, and 7.2.

A combined total of approximately 94 million gallons of contaminated groundwater was extracted and treated during the operation of the aquifer restoration systems at Utica from December 1, 2010, to November 30, 2011. Approximately 77\% of the total volume treated (72.5 million gallons; 223 acre-feet) was used to supplement the natural water entering the North Lake Basin Wildlife Management Area.

Discharge of treated groundwater to the wetlands was not possible during four months of the current review period, because of

- Inclement winter weather conditions (December 2010-February 2011) and

- A temporary shutdown of the extraction wells (beginning in October 2011 and continuing through the end of the review period) to facilitate repairs to the groundwater delivery system components at the northern wetlands spray treatment site.

Groundwater modeling studies during the development of the aquifer restoration approach for Utica (Argonne 2000) indicated that, on average, the extraction of approximately 97 million gallons of groundwater per year would be required to maintain hydraulic control of the groundwater plume and achieve cleanup of the aquifer in an estimated 10-15 yr. The actual groundwater produced during the 2010-2011 review period represents approximately $97 \%$ of this average annual goal. The highest annual production to date (approximately 119 million gallons; $123 \%$ of the annual target) was achieved in the 2006-2007 monitoring period. The cumulative volume of groundwater extracted and treated by the Utica systems since the aquifer restoration efforts began (Table 7.2) now represents $90 \%$ of the theoretical cumulative target for the 7 -yr period November 2004-November 2011 (up slightly from 88\% for the previous 6-yr period, 2004-2010).

The original modeling studies (Argonne 2000) suggested that the natural groundwater flow and contaminant migration rates at this site are sufficiently low to accommodate periodic 
fluctuations in the volume of groundwater extracted annually, as long as the target average extraction rate is generally maintained. The relatively low groundwater recoveries observed during several previous review periods (particularly 2004-2005 and 2007-2008) therefore do not represent an immediate concern. The observed trends in carbon tetrachloride concentrations documented at wells GWEX1-GWEX4 (Section 5.4; Figures 5.2-5.5), together with the results of the 5-yr performance review conducted in 2010 (Argonne 2011b), demonstrate that the combined extraction well system continues to prove effective in removing carbon tetrachloride contamination from the Utica aquifer and restricting downgradient migration of the contaminant plume.

Sampling and analysis of the effluent water from the air stripping and spray irrigation treatment units indicated that during the 2010-2011 review period these systems functioned at a minimum efficiency of $>97 \%$ (on the basis of data for individual samples from the spray treatment units). Efficiencies of $>99 \%$ were calculated for the spray treatment units on the basis of the average concentration delivered to the wetlands during the review period, as well as for the outfall from the air stripping unit. Carbon tetrachloride concentrations in all discharges of treated water at the site were below the permitted maximum target $(44.2 \mu \mathrm{g} / \mathrm{L})$ by roughly two orders of magnitude.

Calculations based on the volumes and measured carbon tetrachloride concentrations of the groundwater extracted and treated during the review period indicate that approximately $7.0 \mathrm{~kg}$ (1.1 gal) of carbon tetrachloride was removed from the Utica aquifer during the 20102011 review period. No decrease in the volumetric throughput (when operating) or contaminant removal efficiency of the groundwater treatment systems was observed during the current period (Table 7.1). Table 5.4 shows that approximately $115.3 \mathrm{~kg}$ (18.1 gal) of carbon tetrachloride has been removed from the Utica aquifer during the first $7 \mathrm{yr}$ of operation of the Utica treatment systems (November 2004 to November 2011).

The costs incurred by Argonne for operating and maintenance of the aquifer restoration effort at Utica during the 2010-2011 review period were approximately $\$ 149,868$, reflecting an increase of approximately $3.5 \%$ in total costs but a decrease of approximately $6.8 \%$ in routine costs relative to the previous (December 2009-November 2010) review period. Expected additional costs associated with the repairs initiated at the north spray pad pipeline vault during the current review period will be included in the next (December 2011-November 2012) annual report. 
TABLE 7.1 Summary of performance of the groundwater restoration systems at Utica.

\begin{tabular}{|c|c|c|c|c|c|c|c|}
\hline & \multicolumn{7}{|c|}{ Review Period } \\
\hline & $\begin{array}{l}\text { Oct 2004- } \\
\text { Nov } 2005\end{array}$ & $\begin{array}{l}\text { Dec 2005- } \\
\text { Nov } 2006\end{array}$ & $\begin{array}{l}\text { Dec 2006- } \\
\text { Nov } 2007\end{array}$ & $\begin{array}{l}\text { Dec 2007- } \\
\text { Nov } 2008\end{array}$ & $\begin{array}{l}\text { Dec 2008- } \\
\text { Nov } 2009\end{array}$ & $\begin{array}{l}\text { Dec 2009- } \\
\text { Nov } 2010\end{array}$ & $\begin{array}{l}\text { Dec 2010- } \\
\text { Nov 2011 }\end{array}$ \\
\hline $\begin{array}{l}\text { Groundwater Produced (gal) } \\
\text { Groundwater Produced (\% of annual goal) } \\
\text { Groundwater DIscharged to Wetlands (gal) }\end{array}$ & $\begin{array}{r}66,364,652 \\
68 \\
34,611,960\end{array}$ & $\begin{array}{c}113,949,510 \\
117 \\
84,365,500\end{array}$ & $\begin{array}{r}119,274,680 \\
123 \\
90,954,300\end{array}$ & $\begin{array}{r}55,228,674 \\
57 \\
25,675,200\end{array}$ & $\begin{array}{r}76,693,459 \\
79 \\
50,633,300\end{array}$ & $\begin{array}{r}83,271,154 \\
86 \\
71,898,100\end{array}$ & $\begin{array}{r}94,190,216 \\
97 \\
72,514,400\end{array}$ \\
\hline 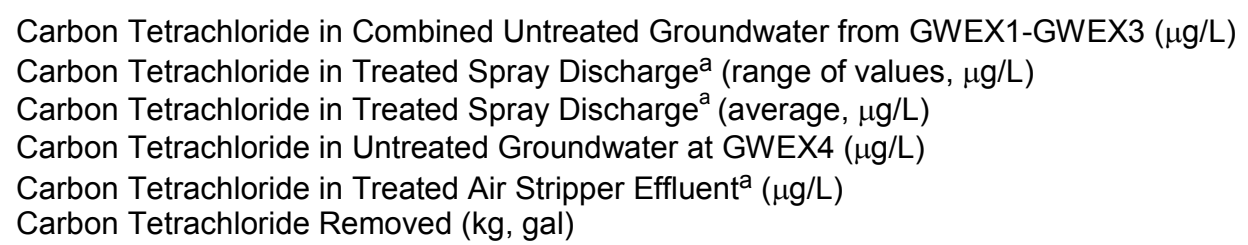 & $\begin{array}{l}100-122 \\
\mathrm{ND}-\mathrm{b}-2 \\
1.45 \\
53-95 \\
\mathrm{ND} \\
23,3.8\end{array}$ & $\begin{array}{l}71-139 \\
\text { ND-6.9 } \\
0.91 \\
26-70 \\
\text { ND } \\
34,5.6\end{array}$ & $\begin{array}{l}48-90 \\
\mathrm{ND}-3.7 \\
0.61 \\
20-43 \\
\mathrm{ND} \\
25,4.1\end{array}$ & $\begin{array}{c}43-89 \\
\text { ND-4.0 } \\
1.13 \\
13-24 \\
\text { ND } \\
8,1.3\end{array}$ & $\begin{array}{l}30-65 \\
\text { ND-1.9 } \\
0.28 \\
6.1-16 \\
\text { ND } \\
9.3,1.5\end{array}$ & $\begin{array}{c}22-53 \\
\text { ND-1.6 } \\
0.17 \\
3.5-11 \\
\text { ND } \\
8.74,1.4\end{array}$ & $\begin{array}{c}18-35 \\
\mathrm{ND}-0.7 \mathrm{~J}^{\mathrm{c}} \\
<0.1 \\
3.8-8.6 \\
\mathrm{ND} \\
7.02,1.1\end{array}$ \\
\hline $\begin{array}{l}\text { Minimum Carbon Tetrachloride Removal Efficiency for Spray Treatment (\%) } \\
\text { Based on Individual Samples } \\
\text { Based on Averages }\end{array}$ & $\begin{array}{l}>94 \\
\sim 99\end{array}$ & $\begin{array}{l}>93 \\
\sim 99\end{array}$ & $\begin{array}{l}>95 \\
\sim 98\end{array}$ & $\begin{array}{l}>92 \\
\sim 98\end{array}$ & $\begin{array}{l}>94 \\
\sim 99\end{array}$ & $\begin{array}{l}>94 \\
\sim 99\end{array}$ & $\begin{array}{l}>97 \\
>99\end{array}$ \\
\hline Carbon Tetrachloride Removal Efficiency for Air Stripper (\%) & $>99$ & $>99$ & $>99$ & $>99$ & $>99$ & $>99$ & $>99$ \\
\hline $\begin{array}{l}\text { pH of Treated Spray Discharge } \\
\text { pH of Treated Air Stripper Effluent }\end{array}$ & $\begin{array}{l}7.01-8.18 \\
7.01-8.35\end{array}$ & $\begin{array}{l}7.10-8.32 \\
7.50-8.58\end{array}$ & $\begin{array}{l}7.09-8.36 \\
7.79-8.33\end{array}$ & $\begin{array}{l}7.88-8.51 \\
7.71-8.41\end{array}$ & $\begin{array}{l}7.48-8.43 \\
6.73-8.45\end{array}$ & $\begin{array}{l}7.40-8.73 \\
7.98-8.36\end{array}$ & $\begin{array}{l}7.45-8.50 \\
7.10-8.04\end{array}$ \\
\hline $\begin{array}{l}\text { Costs (\$) } \\
\text { Routine } \\
\text { Non-routine } \\
\text { TOTAL }\end{array}$ & $\begin{array}{l}270,879 \\
11,707 \\
282,586\end{array}$ & $\begin{array}{l}208,186 \\
62,731 \\
270,916\end{array}$ & $\begin{array}{c}126,720 \\
7,336 \\
134,056\end{array}$ & $\begin{array}{c}156,006 \\
12,075 \\
168,081\end{array}$ & $\begin{array}{l}133,937 \\
26,164 \\
160,101\end{array}$ & $\begin{array}{c}140,140 \\
4,645 \\
144,785\end{array}$ & $\begin{array}{c}130,672 \\
19,196 \\
149,868\end{array}$ \\
\hline
\end{tabular}

a Compliance level, $44.2 \mu \mathrm{g} / \mathrm{L}$.

b ND, not detected at a method detection limit of $0.1 \mu \mathrm{g} / \mathrm{L}$.

c Qualifier $\mathrm{J}$ indicates an estimated concentration below the quantitation limit of $1 \mu \mathrm{g} / \mathrm{L}$ for the purge-and-trap method.

d Compliance level, 6.5-9.0. 
TABLE 7.2 Results of the groundwater extraction efforts, October 2004-November 2011.

\begin{tabular}{|c|c|c|c|}
\hline \multirow[b]{2}{*}{$\begin{array}{l}\text { Period of } \\
\text { Operation }\end{array}$} & \multicolumn{2}{|c|}{ Production (gal) } & \multirow{2}{*}{$\begin{array}{l}\text { Groundwater } \\
\text { Produced } \\
\text { ( } \% \text { of } \\
\text { annual goal) }\end{array}$} \\
\hline & $\begin{array}{l}\text { GWEX1- } \\
\text { GWEX3 }\end{array}$ & GWEX4 & \\
\hline 2004-2005 & $34,611,960$ & $31,752,692$ & 68 \\
\hline $2005-2006$ & $84,365,500$ & $29,584,010$ & 117 \\
\hline 2006-2007 & $90,954,300$ & $28,320,380$ & 123 \\
\hline $2007-2008$ & $25,675,200$ & $29,553,474$ & 57 \\
\hline 2008-2009 & $50,633,300$ & $26,060,159$ & 79 \\
\hline 2009-2010 & $71,898,100$ & $11,373,054$ & 86 \\
\hline $2010-2011$ & $72,514,400$ & $21,675,816$ & 97 \\
\hline TOTAL & $430,652,760$ & $178,319,585$ & \\
\hline AVERAGE & & & 90 \\
\hline
\end{tabular}




\section{References}

Argonne, 2000, Final Report: Stage I Investigations of the Agricultural/Environmental Enhancement Pilot Program, Utica, Nebraska, prepared for the Commodity Credit Corporation, U.S. Department of Agriculture, by Argonne National Laboratory, Argonne, Illinois, January.

Argonne, 2003, Update on Groundwater Sampling Results for Utica, Nebraska, and Pumping Alternatives for the Utica Aquifer/Wetlands Restoration Pilot Program, ANL/ER/AGEM/CHRON-484, prepared for the Commodity Credit Corporation, U.S. Department of Agriculture, by Argonne National Laboratory, Argonne, Illinois, April 9.

Argonne, 2004, Final Monitoring Plan for the Utica Aquifer-North Lake Basin Restoration Project at Utica, Nebraska, ANL/ER/TR-04/006, prepared for the Commodity Credit Corporation, U.S. Department of Agriculture, by Argonne National Laboratory, Argonne, Illinois, November.

Argonne, 2005, Summary of First-Year Operations and Performance of the Utica Aquifer and North Lake Basin Wetlands Restoration Project in October 2004-November 2005, ANL/EVS/AGEM/TR-05-06, prepared for the Commodity Credit Corporation, U.S. Department of Agriculture, by Argonne National Laboratory, Argonne, Illinois, December.

Argonne, 2006, Summary of Operations and Performance of the Utica Aquifer and North Lake Basin Wetlands Restoration Project in December 2005-November 2006, ANL/EVS/AGEM/TR06-11, prepared for the Commodity Credit Corporation, U.S. Department of Agriculture, by Argonne National Laboratory, Argonne, Illinois, December.

Argonne, 2008, Summary of Operations and Performance of the Utica Aquifer and North Lake Basin Wetlands Restoration Project in December 2006-November 2007, ANL/EVS/AGEM/TR08-05, prepared for the Commodity Credit Corporation, U.S. Department of Agriculture, by Argonne National Laboratory, Argonne, Illinois, February.

Argonne, 2009, Summary of Operations and Performance of the Utica Aquifer and North Lake Basin Wetlands Restoration Project in December 2007-November 2008, ANL/EVS/AGEM/TR09-02, prepared for the Commodity Credit Corporation, U.S. Department of Agriculture, by Argonne National Laboratory, Argonne, Illinois, January. 
Argonne, 2010, Summary of Operations and Performance of the Utica Aquifer and North Lake Basin Wetlands Restoration Project in December 2008-November 2009, ANL/EVS/AGEM/TR10-01, prepared for the Commodity Credit Corporation, U.S. Department of Agriculture, by Argonne National Laboratory, Argonne, Illinois, February.

Argonne, 2011a, Summary of Operations and Performance of the Utica Aquifer and North Lake Basin Wetlands Restoration Project in December 2009-November 2010, ANL/EVS/AGEM/TR11-01, prepared for the Commodity Credit Corporation, U.S. Department of Agriculture, by Argonne National Laboratory, Argonne, Illinois, February.

Argonne, 2011b, Five-Year Summary and Evaluation of Operations and Performance of the Utica Aquifer and North Lake Basin Wetlands Restoration Project in 2004-2009, ANL/EVS/AGEM/TR-11-05, prepared for the Commodity Credit Corporation, U.S. Department of Agriculture, by Argonne National Laboratory, Argonne, Illinois, June. 
Argonne

Environmental Science Division

Argonne National Laboratory

9700 South Cass Avenue, BIdg. 203

Argonne, IL 60439-4843

www.anl.gov 